\title{
Occupational health research priorities in Malaysia: a Delphi study
}

\author{
S Sadhra, J R Beach, T-C Aw, K Sheikh-Ahmed
}

\begin{abstract}
Objectives-As part of a consultancy project on occupational health, the Delphi method was used to identify research priorities in occupational health in Malaysia. Methods-Participation was sought from government ministries, industry, and professional organisations, and university departments with an interest in occupational and public health. Two rounds of questionnaires resulted in a final list of priorities, with noticeable differences between participants depending on whether they worked in industry or were from government organisations.
\end{abstract}

Results-The participation rate of $71 \%$ (55 of 78) was obtained for the first questionnaire and $76 \%$ (72 of 95 ) for the second questionnaire. The participants identified occupational health problems for specific groups and industries as the top research priority area (ranked as top priority by $25 \%$ of participants). Ministry of Health participants placed emphasis on healthcare workers (52\% ranking it as top priority), whereas those from industry identified construction and plantation workers as groups, which should be accorded the highest priority. Evaluation of research and services was given a low priority.

Conclusions-The priorities for occupational health determined with the Delphi approach showed differences between Malaysia, a developing country, and findings from similar European studies. This may be expected, as differences exist in stages of economic development, types of industries, occupational activities, and cultural attitudes to occupational health and safety. Chemical poisonings and workplace accidents were accorded a high priority. By contrast with findings from western countries, workplace psychosocial problems and musculoskeletal injuries were deemed less important. There also seemed to be greater emphasis on adopting interventions for identified problems based on experience in other countries rather than the need to evaluate local occupational health provisions.

(Occup Environ Med 2001;58:426-431)

Keywords: occupational health; research priorities; Malaysia

As occupational health and safety is a multidisciplinary field that requires collaboration between individual people and organisations with different expertise and functions for its goals to be achieved, broad consensus should be obtained from as many people and organisations as possible. This study, with the Delphi approach to obtain broad consensus for research priorities in occupational health, is the first of its type from a developing countryMalaysia.

Malaysia has a population of over 21 million, with 13 million workers in more than 600000 workplaces. However, it has been estimated that of these workplaces less than $4 \%$ had more than 10 workers. ${ }^{1}$ The small workplaces include smallholders, contract labourers, and self employed workers. Rapid industrialisation has resulted in a change in the distribution of economic activity within Malaysia. High employment growth in the manufacturing services and construction sector have replaced agriculture and other primary industries where there has been relatively sluggish growth. ${ }^{2}$ These shifts have occurred in tandem with changes in the epidemiology of several diseases within Malaysia. The prevalence of communicable diseases has declined with a concomitant increase in non-communicable diseases. In 1960 the principal causes of hospital admissions were gastroenteritis, tuberculosis, and malaria. In 1990, cardiovascular disease, neoplasms, accidents, and mental disorders were more predominant. ${ }^{3}$

Between 1985 and 1988 the number of cases of occupational diseases and injuries compensated within Malaysia rose by $40 \%{ }^{2}$ This may have been due partly to improved medical services and systems for administration of benefits, but probably also reflects a true increased incidence. The available data indicate significant underrecognition and reporting of occupational injuries and diseases rather than their successful prevention. Thus, occupational and work related disease remains a considerable problem within Malaysia.

In recognition of the need for research into health issues, a government central fund for research and development was created during the fifth Malaysia Plan (1986-1990). The fund was administered by the Ministry of Science, Technology, and Environment with a process termed intensified research priority areas, which generated a list of health research priorities. The list was subsequently reviewed for the seventh Malaysia Plan (1996-2000) and seven target areas for research were identified. Occupational and environmental health was one of these target areas. ${ }^{4}$

Research in the field of occupational health and safety is an essential aspect of the promotion of health at work. Such research can provide essential information about occupational health priorities within Malaysia. One of 
Table 1 Priority listing of the five broad research areas

\begin{tabular}{|c|c|c|c|}
\hline \multirow[b]{2}{*}{ Broad topic areas of research } & \multicolumn{3}{|c|}{ Respondents } \\
\hline & $\begin{array}{l}\text { All } \\
(n=72)\end{array}$ & $\begin{array}{l}M O H \\
(n=21)\end{array}$ & $\begin{array}{l}\text { Industry } \\
(n=32)\end{array}$ \\
\hline $\begin{array}{l}\text { Occupational health problems for specific } \\
\text { occupational groups/industries (hazard types, } \\
\text { number exposed, extent of injuries and diseases, etc) }\end{array}$ & $\begin{array}{l}2.58^{\star} \\
25 \% \dagger \\
1 \ddagger\end{array}$ & $\begin{array}{l}2.62^{\star} \\
19 \% \dagger \\
3 \ddagger\end{array}$ & $\begin{array}{l}2.50^{\star} \\
25 \% \dagger \\
2 \ddagger\end{array}$ \\
\hline $\begin{array}{l}\text { Investigation of specific occupational health } \\
\text { problems (poisoning, noise induced hearing loss, } \\
\text { occupational asthma, etc) }\end{array}$ & $\begin{array}{l}2.63^{\star} \\
18 \% \dagger \\
2 \ddagger\end{array}$ & $\begin{array}{l}2.28^{\star} \\
24 \% \dagger \\
2 \ddagger\end{array}$ & $\begin{array}{l}2.75^{\star} \\
19 \% \dagger \\
3 \ddagger\end{array}$ \\
\hline $\begin{array}{l}\text { Incidence and prevalence of work related diseases } \\
\text { (development of reporting systems, diagnostic } \\
\text { criteria, etc) }\end{array}$ & $\begin{array}{l}2.72^{\star} \\
34 \% \dagger \\
3 \ddagger\end{array}$ & $\begin{array}{l}2.05^{\star} \\
52 \% \dagger \\
1 \ddagger\end{array}$ & $\begin{array}{l}3.28^{\star} \\
22 \% \dagger \\
4 \ddagger\end{array}$ \\
\hline $\begin{array}{l}\text { Health problems associated with industrial } \\
\text { development (air quality, accidents, haze, etc) }\end{array}$ & $\begin{array}{l}3.09^{\star} \\
18 \% \dagger \\
4 \ddagger\end{array}$ & $\begin{array}{l}3.95^{\star} \\
5 \% \dagger \\
4 \ddagger\end{array}$ & $\begin{array}{l}2.46^{\star} \\
28 \% \dagger \\
1 \ddagger\end{array}$ \\
\hline Evaluation of occupational health services & $\begin{array}{l}4.04^{\star} \\
4 \% \dagger \\
5 \ddagger\end{array}$ & $\begin{array}{l}4.09^{\star} \\
5 \% \dagger \\
5 \ddagger\end{array}$ & $\begin{array}{l}5.65^{\star} \\
6 \% \dagger \\
5 \ddagger\end{array}$ \\
\hline
\end{tabular}

Score range 1-5: a mean score of 1 indicates the highest priority; a mean score of 5 indicates the lowest priority.

*Mean ranking score for each topic.

†Percentage of participants ranking the topic as top priority (score of 1 ).

$\ddagger$ Overall rank order for each respondent group using the mean ranking scores.

$\mathrm{MOH}=$ Ministry of Health; $n=$ number of respondents which includes $\mathrm{MOH}$ (21), industry (32), and 19 others from universities and other government departments.

the most difficult questions that needs to be

Table 2 Priority list for specific occupational health groups/industries

\begin{tabular}{|c|c|c|c|}
\hline \multirow[b]{2}{*}{ Specific areas of concern } & \multicolumn{3}{|c|}{ Respondents } \\
\hline & $\begin{array}{l}\text { All } \\
(n=72)\end{array}$ & $\begin{array}{l}\text { MOH } \\
(n=21)\end{array}$ & $\begin{array}{l}\text { Industry } \\
(n=32)\end{array}$ \\
\hline Construction workers & $\begin{array}{l}3.90^{\star} \\
21 \% \dagger \\
1 \neq\end{array}$ & $\begin{array}{l}3.95^{\star} \\
14 \% \dagger \\
2 \ddagger\end{array}$ & $\begin{array}{l}3.47^{\star} \\
22 \% \dagger \\
2 \ddagger\end{array}$ \\
\hline Pesticide sprayers & $\begin{array}{l}3.94^{\star} \\
14 \% \dagger \\
2 \ddagger\end{array}$ & $\begin{array}{l}3.95^{\star} \\
14 \% \dagger \\
2 \ddagger\end{array}$ & $\begin{array}{l}3.91^{\star} \\
19 \% \dagger \\
3 \ddagger\end{array}$ \\
\hline Plantation workers & $\begin{array}{l}4.22^{\star} \\
11 \% \dagger \\
3 \ddagger\end{array}$ & $\begin{array}{l}4.67^{\star} \\
10 \% \dagger \\
4 \ddagger\end{array}$ & $\begin{array}{l}3.09^{\star} \\
13 \% \dagger \\
1 \neq\end{array}$ \\
\hline Healthcare workers & $\begin{array}{l}5.45^{\star} \\
22 \% \dagger \\
4 \ddagger\end{array}$ & $\begin{array}{l}2.52^{\star} \\
52 \% \dagger \\
1 \ddagger\end{array}$ & $\begin{array}{l}6.81^{\star} \\
13 \% \dagger \\
8 \ddagger\end{array}$ \\
\hline Migrant workers & $\begin{array}{l}6.01^{\star} \\
6 \% \dagger \\
5 \ddagger\end{array}$ & $\begin{array}{l}7.33^{\star} \\
0 \% \dagger \\
7 \ddagger\end{array}$ & $\begin{array}{l}5.12^{\star} \\
9 \% \dagger \\
4 \ddagger\end{array}$ \\
\hline Quarry and mine workers & $\begin{array}{l}6.04^{\star} \\
1 \% \dagger \\
6 \ddagger\end{array}$ & $\begin{array}{l}6.71^{\star} \\
5 \% \dagger \\
6 \ddagger\end{array}$ & $\begin{array}{l}5.25^{\star} \\
6 \% \dagger \\
5 \ddagger\end{array}$ \\
\hline Small scale industries & $\begin{array}{l}6.21^{\star} \\
11 \% \dagger \\
7 \ddagger\end{array}$ & $\begin{array}{l}5.57^{\star} \\
10 \% \dagger \\
5 \ddagger\end{array}$ & $\begin{array}{l}6.56^{\star} \\
13 \% \dagger \\
6 \ddagger\end{array}$ \\
\hline Electronic industry & $\begin{array}{l}6.79^{\star} \\
6 \% \dagger \\
8 \ddagger\end{array}$ & $\begin{array}{l}7.38^{\star} \\
0 \% \dagger \\
9 \ddagger\end{array}$ & $\begin{array}{l}6.75^{\star} \\
6 \% \dagger \\
7 \ddagger\end{array}$ \\
\hline Commercial and heavy vehicle drivers & $\begin{array}{l}6.92^{\star} \\
0 \% \dagger \\
9 \ddagger\end{array}$ & $\begin{array}{l}7.38^{\star} \\
0 \% \dagger \\
9 \ddagger\end{array}$ & $\begin{array}{l}6.91^{\star} \\
0 \% \dagger \\
9 \ddagger\end{array}$ \\
\hline Woodworkers & $\begin{array}{l}7.39^{\star} \\
0 \% \dagger \\
10 \ddagger\end{array}$ & $\begin{array}{l}7.19^{\star} \\
5 \% \dagger \\
8 \ddagger\end{array}$ & $\begin{array}{l}7.03^{\star} \\
0 \% \dagger \\
10 \ddagger\end{array}$ \\
\hline Hotel and restaurant workers & $\begin{array}{l}10.53^{\star} \\
0 \% \dagger \\
11 \neq\end{array}$ & $\begin{array}{l}10.86^{\star} \\
0 \% \dagger \\
12 \ddagger\end{array}$ & $\begin{array}{l}10.44^{\star} \\
0 \% \dagger \\
11 \ddagger\end{array}$ \\
\hline Administrative workers & $\begin{array}{l}10.73^{\star} \\
0 \% \dagger \\
12 \ddagger\end{array}$ & $\begin{array}{l}10.48^{\star} \\
0 \% \dagger \\
11 \ddagger\end{array}$ & $\begin{array}{l}11.40^{\star} \\
0 \% \dagger \\
12 \ddagger\end{array}$ \\
\hline
\end{tabular}

For explanations see table 1. considered in occupational health research is the selection of research priorities. Numerous methods for setting priorities have been described but an innovative approach is the Delphi technique, which has been used to establish research priorities in the United Kingdom ${ }^{5}$ and The Netherlands. ${ }^{6}$ Loo $1996^{7}$ used the Delphi technique to identify future organisational policy for managing stress among human resource managers.

The Delphi technique ${ }^{8}$ involves the administration of a series of questionnaires to selected people. Initially, participants are asked to respond to a broad question on a general subject area. Subsequent questionnaires are modified and focused based upon responses to the first questionnaire. The iterative process stops when consensus has been reached among participants. Analysis of the questionnaires can be used to prioritise research areas and to rank specific research issues within these areas.

In 1997-8, a British Council project on occupational health in Malaysia included a Delphi exercise to identify research priorities in occupational health in Malaysia. ${ }^{9}$ This paper reports the results of that exercise.

\section{Methods}

SUBJECTS AND METHODS

Staff from the occupational health unit of the Ministry of Health, Malaysia, produced a list of all organisations with an interest in occupational health. These organisations were grouped into those representing government departments, universities, and major industries (mainly large industries with occupational health departments). Sufficient publicity was given through preliminary meetings with representatives from the different organisations to promote participation in the exercise. Representatives from all organisations in the three groups were then formally invited to participate in the study by letter.

For phase one of the study, all 78 respondents were invited to complete the first questionnaire. Of these $42(54 \%)$ were in government service including $22(28 \%)$ from the Ministry of Health, $30(38 \%)$ were from industry, and six $(8 \%)$ from the two Malaysian universities with specialists in occupational medicine. For phase two a second questionnaire was sent to all those who participated in phase one plus an additional 17 people from the same organisations that had expressed an interest in this phase of the study. Of the 95 people invited to participate in phase two, 49 (52\%) worked for the government, $40(42 \%)$ in industry, and six $(6 \%)$ were from the universities.

The study participants comprised occupational health and safety professionals working within Malaysian industry with and without specific occupational health and safety training or qualifications; representatives of industries with occupational health services; people or organisations involved in occupational health and safety training, research, planning or consultancy; and organisations or centres collecting data on current occupational and safety activities. 
Table 3 Priority list of specific occupational health problems for research

\begin{tabular}{|c|c|c|c|}
\hline \multirow[b]{2}{*}{ Specific areas of concern } & \multicolumn{3}{|c|}{ Respondents } \\
\hline & $\begin{array}{l}\text { All } \\
(n=72)\end{array}$ & $\begin{array}{l}\mathrm{MOH} \\
(n=21)\end{array}$ & $\begin{array}{l}\text { Industry } \\
(n=32)\end{array}$ \\
\hline Chemical poisoning (metals, pesticides, solvents) & $\begin{array}{l}2.79^{\star} \\
34 \% \dagger \\
1 \ddagger\end{array}$ & $\begin{array}{l}3.57^{\star} \\
33 \% \dagger \\
2 \ddagger\end{array}$ & $\begin{array}{l}2.44^{\star} \\
31 \% \dagger \\
1 \neq\end{array}$ \\
\hline Injuries at work from industrial accidents & $\begin{array}{l}2.96^{\star} \\
35 \% \dagger \\
2 \ddagger\end{array}$ & $\begin{array}{l}3.14^{\star} \\
33 \% \dagger \\
1 \neq\end{array}$ & $\begin{array}{l}2.66^{\star} \\
41 \% \dagger \\
2 \ddagger\end{array}$ \\
\hline Noise induced hearing loss & $\begin{array}{l}4.32^{\star} \\
7 \% \dagger \\
3 \ddagger\end{array}$ & $\begin{array}{l}4.09^{\star} \\
14 \% \dagger \\
4 \ddagger\end{array}$ & $\begin{array}{l}3.96^{\star} \\
3 \% \dagger \\
3 \ddagger\end{array}$ \\
\hline Skin diseases associated with work & $\begin{array}{l}4.52^{\star} \\
6 \% \dagger \\
4 \ddagger\end{array}$ & $\begin{array}{l}3.81^{\star} \\
5 \% \dagger \\
3 \ddagger\end{array}$ & $\begin{array}{l}4.78^{\star} \\
6 \% \dagger \\
5 \ddagger\end{array}$ \\
\hline Occupational lung disease including asthma & $\begin{array}{l}4.75^{\star} \\
7 \% \dagger \\
5 \ddagger\end{array}$ & $\begin{array}{l}4.33^{\star} \\
10 \% \dagger \\
5 \ddagger\end{array}$ & $\begin{array}{l}5.41^{\star} \\
3 \% \dagger \\
7 \ddagger\end{array}$ \\
\hline $\begin{array}{l}\text { Musculoskeletal problems and repetitive strain } \\
\text { injury }\end{array}$ & $\begin{array}{l}4.98^{\star} \\
4 \% \dagger \\
6 \ddagger\end{array}$ & $\begin{array}{l}5.57^{\star} \\
0 \% \dagger \\
7 \ddagger\end{array}$ & $\begin{array}{l}4.59^{\star} \\
6 \% \dagger \\
4 \ddagger\end{array}$ \\
\hline Work related back problems & $\begin{array}{l}5.18^{\star} \\
4 \% \dagger \\
7 \ddagger\end{array}$ & $\begin{array}{l}5.28^{\star} \\
5 \% \dagger \\
6 \neq\end{array}$ & $\begin{array}{l}5.16^{\star} \\
3 \% \dagger \\
6 \ddagger\end{array}$ \\
\hline Psychological disorders (stress at work) & $\begin{array}{l}6.0^{\star} \\
3 \% \dagger \\
8 \ddagger\end{array}$ & $\begin{array}{l}6.09^{\star} \\
0 \% \dagger \\
8 \ddagger\end{array}$ & $\begin{array}{l}6.22^{\star} \\
6 \% \dagger \\
8 \ddagger\end{array}$ \\
\hline
\end{tabular}

For explanations see table 1 .

Two questionnaires were administered, the second a month after the first. The first Delphi questionnaire administered had an open ended question asking respondents to identify three broad priority areas for occupational health research with respect to "research needs for knowledge, assessment, and management of occupational related ill health". The top five choices for main research areas were noted. Under these five broad areas the respondents identified a series of specific items ranging

Table 4 Priority list of specific clinical occupational health areas for research

\begin{tabular}{|c|c|c|c|}
\hline \multirow[b]{2}{*}{ Specific areas of concern } & \multicolumn{3}{|c|}{ Respondents } \\
\hline & $\begin{array}{l}\text { All } \\
(n=72)\end{array}$ & $\begin{array}{l}\text { MOH } \\
(n=21)\end{array}$ & $\begin{array}{l}\text { Industry } \\
(n=32)\end{array}$ \\
\hline Mechanical equipment injuries or accidents & $\begin{array}{l}2.70^{\star} \\
42 \% \dagger \\
1 \neq\end{array}$ & $\begin{array}{l}3.23^{\star} \\
29 \% \dagger \\
3 \ddagger\end{array}$ & $\begin{array}{l}2.25^{\star} \\
47 \% \dagger \\
1 \neq\end{array}$ \\
\hline Chemical poisoning & $\begin{array}{l}3.00^{\star} \\
28 \% \dagger \\
2 \ddagger\end{array}$ & $\begin{array}{l}3.23^{\star} \\
24 \% \dagger \\
4 \ddagger\end{array}$ & $\begin{array}{l}3.28^{\star} \\
22 \% \dagger \\
3 \ddagger\end{array}$ \\
\hline Noise induced hearing loss & $\begin{array}{l}3.41^{\star} \\
13 \% \dagger \\
3 \ddagger\end{array}$ & $\begin{array}{l}3.09^{\star} \\
29 \% \dagger \\
2 \ddagger\end{array}$ & $\begin{array}{l}3.09^{\star} \\
9 \% \dagger \\
2 \ddagger\end{array}$ \\
\hline Occupational asthma & $\begin{array}{l}3.77^{\star} \\
3 \% \dagger \\
4 \ddagger\end{array}$ & $\begin{array}{l}2.95^{\star} \\
10 \% \dagger \\
1 \ddagger\end{array}$ & $\begin{array}{l}4.28^{\star} \\
0 \% \dagger \\
5 \ddagger\end{array}$ \\
\hline Occupational dermatitis & $\begin{array}{l}4.01^{\star} \\
9 \% \dagger \\
5 \ddagger\end{array}$ & $\begin{array}{l}3.47^{\star} \\
10 \% \dagger \\
5 \ddagger\end{array}$ & $\begin{array}{l}4.06^{\star} \\
13 \% \dagger \\
4 \ddagger\end{array}$ \\
\hline Occupational cancer & $\begin{array}{l}5.36^{\star} \\
3 \% \dagger \\
6 \ddagger\end{array}$ & $\begin{array}{l}6.09^{\star} \\
0 \% \dagger \\
7 \ddagger\end{array}$ & $\begin{array}{l}5.53^{\star} \\
3 \% \dagger \\
7 \ddagger\end{array}$ \\
\hline Suicide or depression & $\begin{array}{l}5.72^{\star} \\
3 \% \dagger \\
7 \ddagger\end{array}$ & $\begin{array}{l}5.90^{\star} \\
0 \% \dagger \\
6 \ddagger\end{array}$ & $\begin{array}{l}5.47^{\star} \\
6 \% \dagger \\
6 \ddagger\end{array}$ \\
\hline
\end{tabular}

For explanations see table 1. from five to 12 topics. Also, the participants listed 11 other specific areas, which did not fit under the five broad research areas. The five broad research areas and their subtopics including the specific topics were listed on a second questionnaire.

In the second questionnaire all participants were asked to rank in order of importance each of the five broad headings and their subitems as well as the additional 11 specific topics. For instance, for the five broad areas of research, the score ranged from 1 to 5 , with a score of 1 indicating the highest priority. If there were 10 subtopics within a broad research area then the scores ranged from 1 to 10 . Mean scores for the broad grouping, their subitems, and the 11 specific assorted topics provided the final rank order with the highest priority choice receiving the lowest numerical score. These scores were analysed for all respondents, and also analysed separately for participants working for the Ministry of Health and participants working in industry. Results were not analysed separately for participants from the universities and other government departments, as the number in these groups were relatively small. Sufficient consensus was achieved among questionnaire two respondents to discuss and plan specific research programmes, no further questionnaires were administered. Consensus in this study was defined as a minimum of $25 \%$ of all respondents agreeing on the top priority for the five broad research areas identified from the first questionnaire. A workshop was organised to discuss the findings of the second questionnaire and to assess the feasibility of conducting research in the prioritised specific topic areas.

\section{Results}

A response rate of $71 \%$ (55 of 78) was obtained for the first questionnaire and 76\% (72 of 95) for the second questionnaire. The response rate for the first questionnaire was 79\% (33 of 42) for the government departments and $57 \%$ (17 of 30) for industry. Five of six university participants completed the first questionnaire. For the second questionnaire the response rate for industry was $80 \%$ (32 of 40), for the government departments $71 \%$ (35 of 49), and for the universities five of six responded. The response rate for the Ministry of Health for the second questionnaire was $66 \%$ (21 of 32).

The first questionnaire asked all respondents to identify broad priority areas for occupational health research, the findings of which were used to formulate the second questionnaire. The results from the second questionnaire are shown in tables $1-5$. The mean scores for each of the five main research topic areas are shown in table 1, with the percentage of participants scoring this topic area as their highest priority and the overall ranking for each topic area based on the mean scores. The topic area with the highest overall ranking was occupational health problems for specific groups and industries. Ministry of Health participants gave incidence and prevalence of work related diseases as their highest priority, whereas industry participants gave the highest priority to health 
Table 5 Priority list of specific environmental health problems for research

\begin{tabular}{|c|c|c|c|}
\hline \multirow[b]{2}{*}{ Specific areas of concern } & \multicolumn{3}{|c|}{ Respondents } \\
\hline & $\begin{array}{l}\text { All } \\
(n=72)\end{array}$ & $\begin{array}{l}\mathrm{MOH} \\
(n=21)\end{array}$ & $\begin{array}{l}\text { Industry } \\
(n=32)\end{array}$ \\
\hline Community health effects from industrial pollution & $\begin{array}{l}2.43^{\star} \\
28 \% \dagger \\
1 \ddagger\end{array}$ & $\begin{array}{l}2.14^{\star} \\
43 \% \dagger \\
1 \ddagger\end{array}$ & $\begin{array}{l}2.41^{\star} \\
28 \% \dagger \\
1 \neq\end{array}$ \\
\hline Road accidents (types/injuries/mapping etc) & $\begin{array}{l}3.32^{\star} \\
30 \% \dagger \\
2 \ddagger\end{array}$ & $\begin{array}{l}2.81^{\star} \\
33 \% \dagger \\
2 \ddagger\end{array}$ & $\begin{array}{l}3.50^{\star} \\
28 \% \dagger \\
4 \ddagger\end{array}$ \\
\hline $\begin{array}{l}\text { Community health effects from vehicle emissions } \\
\text { (haze) }\end{array}$ & $\begin{array}{l}3.38^{\star} \\
8 \% \dagger \\
3 \ddagger\end{array}$ & $\begin{array}{l}3.24^{\star} \\
5 \% \dagger \\
3 \ddagger\end{array}$ & $\begin{array}{l}3.47^{\star} \\
9 \% \dagger \\
2 \ddagger\end{array}$ \\
\hline Indoor air quality and health effects & $\begin{array}{l}3.44^{\star} \\
8 \% \dagger \\
4 \ddagger\end{array}$ & $\begin{array}{l}4.38^{\star} \\
5 \% \dagger \\
5 \ddagger\end{array}$ & $\begin{array}{l}4.03^{\star} \\
3 \% \dagger \\
6 \ddagger\end{array}$ \\
\hline $\begin{array}{l}\text { Evaluation of outdoor air quality and the } \\
\text { development of air standards }\end{array}$ & $\begin{array}{l}3.60^{\star} \\
13 \% \dagger \\
5 \ddagger\end{array}$ & $\begin{array}{l}3.62^{\star} \\
14 \% \dagger \\
4 \ddagger\end{array}$ & $\begin{array}{l}3.47^{\star} \\
13 \% \dagger \\
2 \ddagger\end{array}$ \\
\hline $\begin{array}{l}\text { Hazards associated with new industries and new } \\
\text { technology }\end{array}$ & $\begin{array}{l}4.17^{\star} \\
13 \% \dagger \\
6 \pm\end{array}$ & $\begin{array}{l}4.81^{\star} \\
0 \% \dagger \\
6 \pm\end{array}$ & $\begin{array}{l}3.94^{\star} \\
19 \% \dagger \\
5 \pm\end{array}$ \\
\hline
\end{tabular}

For explanations see table 1.
Respondents working in industry perceived health problems associated with industrial development as the most important area for research (table 1). For all participants the highest priority under this broad topic area was community health effects from industrial pollution (table 5). Community health effects from industrialisation were of particular concern to the Ministry of Health with $43 \%$ ranking this as the topic priority. This may reflect the frequency of such issues being raised to the occupational health and safety professionals working in industry. Some participants thought that more guidance was needed on planning environmental impact studies with particular reference to study design, sampling techniques, exposure modelling, and criteria for judging the impact on health.

\section{Discussion}

The Delphi technique has several advantages in reaching consensus. It allows each participant to have an equal say in decision making, and avoids undue influence by assertive people or organisations that can be encountered in decision making by committee.

The technique also has several limitations.

- In common with other methods in which questionnaires are administered, it requires adequate time, a good standard of written communication, and high participant motivation.

- The views obtained depend in part on the selection of participants. For occupational health research priorities, participants should be representative of all relevant sections of the workforce, government, and employers. In this study, the number of participants was limited by practical considerations of time and cost. The industry participants had a predominance of representation from multinational organisations and the agricultural industry. The reason for this was that in Malaysia, many occupational health and safety professionals are employed by these sectors of industry.

- A possible source of observer bias is that the investigators may subconsciously influence responses in the way in which questions are stated, or by omission of topics they themselves do not perceive as important. We do not think that this occurred to any great extent in this study as several different occupational health professionals with divergent backgrounds and representatives of the Ministry of Health, Malaysia, were involved in devising, reviewing, and testing the questionnaires before they were finalised.

The project identified that the most important perceived area for future occupational health research in Malaysia was occupational health problems for specific groups and industries. Of these, the highest priority was given to construction workers. This would be expected to cover research into the type, extent, and cause of injuries, illnesses, and accidents, within the construction industry. Participants from industry also ranked plantation workers occupational cancer were considered to be less important. 
as another important group of workers for further research. The areas of research suggested for this group included the extent of work related injuries and diseases, hazard prevention and control strategies, and health surveillance needs. These research areas seem to be common regardless of the occupational group identified as those warranting top priority-for example, healthcare workers for those from the Ministry of Health, construction workers and plantation workers from participants from industry.

Participants from the Ministry of Health ranked the incidence and prevalence of occupational diseases as the most important area for research. Under this heading, occupational asthma was highlighted. Research into this area could include development of suitable reporting systems for occupational and work related lung diseases including occupational asthma. As a follow up to this exercise, a reporting system for occupational lung diseases, skin diseases, and poisonings was developed by the Ministry of Health, Malaysia. ${ }^{10}$ This was publicised through several training seminars involving hospital clinicians, occupational physicians, and other health and safety personnel-all of whom will have a major role in the identification and reporting of occupational diseases. A benefit of this Delphi exercise was that it led to concrete proposals for improving the notification system for occupational diseases in Malaysia. Another benefit was that criteria for diagnosis of occupational lung diseases and occupational skin diseases in Malaysia were proposed, debated, agreed, and published. ${ }^{11}{ }^{12}$ These were based on data and criteria from several publications, ${ }^{13}$ modified and adapted to be relevant for the clinical conditions common in Malaysia. Specialists in respiratory medicine, dermatology, and occupational health in Malaysia were involved in discussions on the criteria and conditions to be included.

For the 11 specific topics identified from the first questionnaire outside the broad topic areas, there was agreement between industry and Ministry of Health participants on the top priority. This was the need to assess and develop "knowledge, training, and instruments in the prevention of occupational ill health". Updating training and knowledge for occupational health professionals, especially doctors and nurses, was highlighted by many participants. The broad areas suggested for information, instruction, and training included workplace risk assessment, the principles, basis, and procedures for pre-employment screening, indications and techniques for occupational health surveillance, and control technology.

Comparisons can be made between the findings in this study and the views on priorities in occupational health research in developed countries - for example, Finland, the United Kingdom, and The Netherlands. In the early 1970 s, a stated priority for occupational health in Finland was to improve the quality and quantity of research output. ${ }^{14}$ By the early 1980 s, the priority had shifted towards evaluating the effectiveness of research activities and assessment of the relevance of research programmes. In the early 1990s, the emphasis was on examining the practical and societal impact of research, and directing research efforts towards the most important problems within occupational health and safety. Harrington $1994^{5}$ in a Delphi project on occupational health in the United Kingdom, included only physicians based in academic institutions and industry as study participants. The first priority for research was identified to be the natural history of certain work related disorders, the most important being musculoskeletal disorders associated with the back and upper limbs. Van der Beek et al $1997^{6}$ in the Netherlands used supplementary methods as well as the Delphi technique. Some of the opinions were obtained from interviews and workshops. Comparison of the findings from these studies indicates that evaluation of occupational health research has a low priority in Malaysia, a medium priority in the United Kingdom, and a high priority in the Netherlands. These differences may be due entirely to the way in which the questions were phrased, or the way in which the different Delphi studies were done, or may reflect a true difference between participants in the different countries in their research priorities. It is possible that the countries are at different stages along a route that has already been experienced in Finland. Malaysia may be at the beginning of this process as its provisions for occupational health are in their infancy. Hence evaluation of research activity was given a low priority at this stage by most participants, in comparison with higher priority being given to basic issues such as criteria for recognising occupational diseases, the true extent of occupational ill health, and the occupational health and safety concerns of specific occupational groups such as construction workers, plantation workers, and healthcare staff.

\section{Conclusions}

A high perceived priority is only one important factor in determining future research. Rantanen, ${ }^{14}$ when discussing strategic planning in occupational health research highlighted the issue of relevance in the setting of priorities. Assessment of relevance in any research strategy should take into consideration the capacity to solve prioritised perceived problems. These perceived problems in occupational health would vary according to the climate, political and cultural settings, and the stage of economic development of different countries. Although the experience in developed countries could provide lessons for developing countries, the focus on research areas and occupational health solutions for any country should be geared to the conditions and facilities in that country.

Having identified the priority areas in occupational health in Malaysia, the next logical step would be to identify resources for implementing the research. It will also be reasonable to review these research priorities periodically as views change and new issues emerge requiring research in occupational health. 


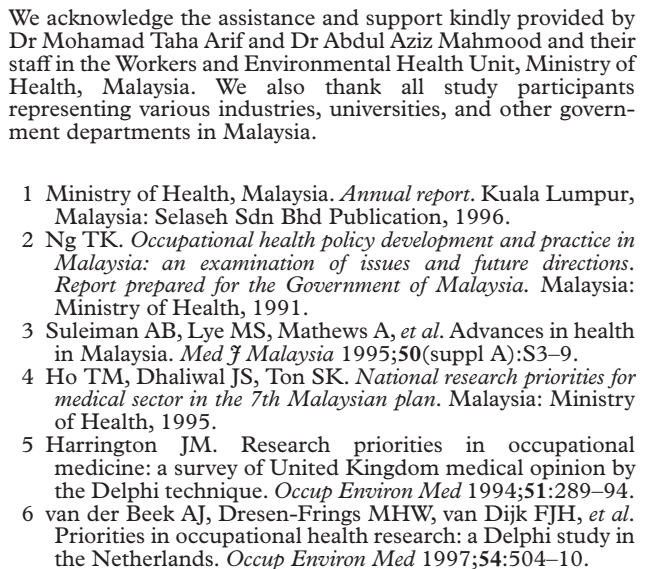

7 Loo R. Managing workplace stress: a Canadian Delphi Loo R. Managing workplace stress: a Canadian Delphi
study among human resource managers. Work Stress 1996; study among

8 Linstone HA, Turoff M, eds. The Delphi method: techniques and applications. Reading, Massachusetts: Addison-Wesley, 1975. 9 Sadhra S. Occupational research development in Malaysia: a report for the Ministry of Health, Malaysia. Manchester, UK: British Council, 1997.

10 Aw TC. Notification of occupational poisonings and injuries: a report for the Ministry of Health, Malaysia. Manchester, UK: British Council, 1996.

11 Beach J. The recognition and notification of occupational lung diseases in Malaysia: report for the Ministry of Health, Malaysia. Manchester, UK: British Council, 1997

12 Aw TC, Aldridge RD. Malaysia health development project: final report of consultancy visits on occupational health for the Ministry of Health, Malaysia. Manchester, UK: British Council, 1998.

13 European Commission. Health and safety: information notices on diagnosis of occupational diseases. Luxembourg: European Commission, 1994

14 Rantanen J. Priority setting and evaluation as tools for planning research strategy. Scand $f$ Work Environ Health 1992;8(suppl 2):5-7.

\section{Answers to multiple choice questions on Cancer after nuclear incidents by C R Muirhead on pages $482-8$}

(1) (a) False: power should be assessed in advance

(b) False: this is a source of bias

(c) False: these studies involve aggregated rather than individual data

(d) True

(e) True

(2) (a) True

(b) False: over half of them were still alive at the end of 1990

(c) False: they have mostly been solid cancers

(d) True

(e) False: there is a linear-quadratic trend for leukaemia

(3) (a) True

(b) False

(c) True

(d) False: the results of a case-control study are consistent with the Japanese A-bomb findings

(e) False: studies have been initiated only in recent years

(4) (a) False: only a raised risk of thyroid cancer has been confirmed

(b) False: most of them have been correlation studies

(c) True

(d) True

(e) False: no association has yet been established between their work and the risk of cancer

(5) (a) False: doses to people living near Chernobyl were much higher than those to people living near Three Mile Island

(b) False: a cohort study did not find an association

(c) True

(d) True, although there are uncertainties associated with these techniques

(e) False 